\title{
Prevalence of intestinal parasite infections in stray and farm dogs from Spain
}

\author{
Prevalência de infecções por parasitos intestinais em cães errantes e de \\ fazenda na Espanha
}

\begin{abstract}
Javier Regidor-Cerrillo1 (1D; David Arranz-Solís ${ }^{1,2}$ (D); Javier Moreno-Gonzalo'; Susana Pedraza-Díaz ${ }^{1,3}$ (D); Mercedes Gomez-Bautista'; Luis Miguel Ortega-Mora1 (1); Esther Collantes-Fernandez * (B)

1 SALUVET, Departamento de Sanidad Animal, Facultad de Veterinaria, Universidad Complutense de Madrid, Madrid, España ${ }^{2}$ Department of Pathology, Microbiology and Immunology, School of Veterinary Medicine, University of California Davis, Davis, California, USA

${ }^{3}$ Toxicología ambiental, Centro Nacional de Sanidad Ambiental - CNSA, Instituto de Salud Carlos III, Majadahonda, España
\end{abstract}

\begin{abstract}
How to cite: Regidor-Cerrillo J, Arranz-Solís D, Moreno-Gonzalo J, Pedraza-Díaz S, Gomez-Bautista M, Ortega-Mora LM, et al. Prevalence of intestinal parasite infections in stray and farm dogs from Spain. Braz J Vet Parasitol 2020; 29(3): e014920. https:// doi.org/10.1590/S1984-29612020063
\end{abstract}

\begin{abstract}
Dogs play a potential role as reservoirs for zoonotic parasites, being especially problematic uncontrolled dog populations such as stray and farm dogs with access to populated areas. In order to investigate the prevalence of canine intestinal parasites in at-risk dog populations, we tested a total of 233 faecal samples shed by stray and dairy farm dogs from northern Spain. Telemann method was used to detect the presence of eggs and (oo)cysts of common dog intestinal parasites and Cryptosporidium was detected by PCR. One hundred and forty eight out of 233 samples (63.5\%) were positive for at least one intestinal parasite, being Ancylostomidae (35.6\%; 83/233) and Trichuris $(35.2 \% ; 82 / 233)$ the parasites most frequently identified. Cryptosporidium DNA was not detected in any of the faecal samples analysed. The overall prevalence was significantly higher in stray dogs than in farm dogs (72.5\% vs 58.8\%). Specifically, stray dogs had a significantly higher prevalence of Ancylostomatidae, Toxocara, Toxascaris and Taenidae. These dog populations are an important source of environmental contamination with intestinal parasite forms, which could be of significance to animal and human health.
\end{abstract}

Keywords: Intestinal parasites, farm dogs, stray dogs, prevalence, coprology.

\begin{abstract}
Resumo
Os cães desempenham um importante papel como reservatório de parasitos zoonóticos, sendo especialmente problemáticas as populações descontroladas, como a de cães errantes e de fazenda, com acesso às áreas povoadas. Para investigar a prevalência de parasitos intestinais em populações caninas de risco, foram analisadas 233 amostras fecais provenientes de cães de fazendas leiteiras e errantes do norte da Espanha. O método Telemann foi utilizado para detectar ovos, cistos e oocistos dos parasitos caninos mais comuns e para a detecção de Cryptosporidium foi utilizada a técnica da PCR. Cento e quarenta e oito de 233 amostras analisadas (63,5\%) foram positivas para pelo menos um parasito intestinal, sendo Ancyostomatidae (35,6\%; 83/233) e Trichuris sp. (35,2\%; 82/233) os parasitos identificados com maior frequência. O DNA de Cryptosporidium sp. não foi detectado em nenhuma das amostras fecais analisadas. A prevalência geral foi significativamente maior em cães errantes do que em cães de fazenda ( $72,5 \%$ vs 58,8\%). Especificamente, os cães errantes tiveram prevalência maior para Ancylostomatidae, Toxocara, Toxascaris e Taenidae. Essas populações de cães são importantes fontes de contaminação ambiental, pois eliminam formas de vida desses parasitos, que podem ter impacto na saúde animal e humana.
\end{abstract}

Palavras-chave: Parasitos intestinais, cães de fazenda, cães errantes, prevalência, coprologia.

Received June 19, 2020. Accepted June 23, 2020.

Financial support: This work was supported by project PR1/06-14467-B (Complutense University of Madrid).

*Corresponding author: Esther Collantes-Fernandez. E-mail: esthercf@ucm.es 


\section{Introduction}

Dogs are hosts to a large number of gastrointestinal parasites and can shed helminth eggs and protozoan oocysts in their faeces (Balassiano et al., 2009; Traversa et al., 2014). The potential role of dogs as reservoirs for zoonotic parasites (such as Giardia spp., Cryptosporidium spp., Toxocara spp., hookworms -Ancylostoma and Uncinaria- and Echinococcus granulosus) has been recognized as a significant public health problem worldwide (Benito et al., 2006; Traversa et al., 2014; Felsmann et al., 2017; Mateus et al., 2014; Saldanha-Elias et al., 2019). Uncontrolled dog populations, such as stray and farm dogs, have access to populated areas, representing a potential risk to public and animal health (Martínez-Moreno et al., 2007; Liberato et al., 2018), mainly in rural areas where there is a close contact between dogs and humans or livestock (Pierangeli et al., 2007; Soriano et al., 2010; Cardoso et al., 2014). However, there are very few investigations on gastrointestinal parasites present in such outdoor dogs that might also present risk as zoonotic reservoirs for human infections, since they are not routinely tested for parasitic infections. The objective of the present study was to determine the prevalence of intestinal parasites in stray and farm dogs in northern Spain.

\section{Material and Methods}

A total of 233 dogs sampled in 2013 from areas located in northern Spain were included in this study: 102 stray dogs from a peri-urban area (La Rioja) and 131 dogs from dairy farms located in one of the main cattle-producing regions in Spain (Lugo, Galicia) (Figure 1). Stray dogs were euthanised according to stray dog control programs of the Municipality, and necropsies were performed. Faecal samples were collected directly from the rectum of the necropsied stray dogs or from the ground after defecation by farm dogs, and submitted refrigerated $\left(4^{\circ} \mathrm{C}\right)$ to our laboratory facilities (SALUVET, Animal Health Department, Faculty of Veterinary Sciences, Complutense University of Madrid, Spain). Samples were processed by the Telemann method (Thienpont et al., 1979) followed by sucrose flotation. One wet mount and one flotation slide were observed for each faecal sample. Identification of parasite cysts, oocysts and eggs was performed by morphological observation at 100-400× magnification. Furthermore, to

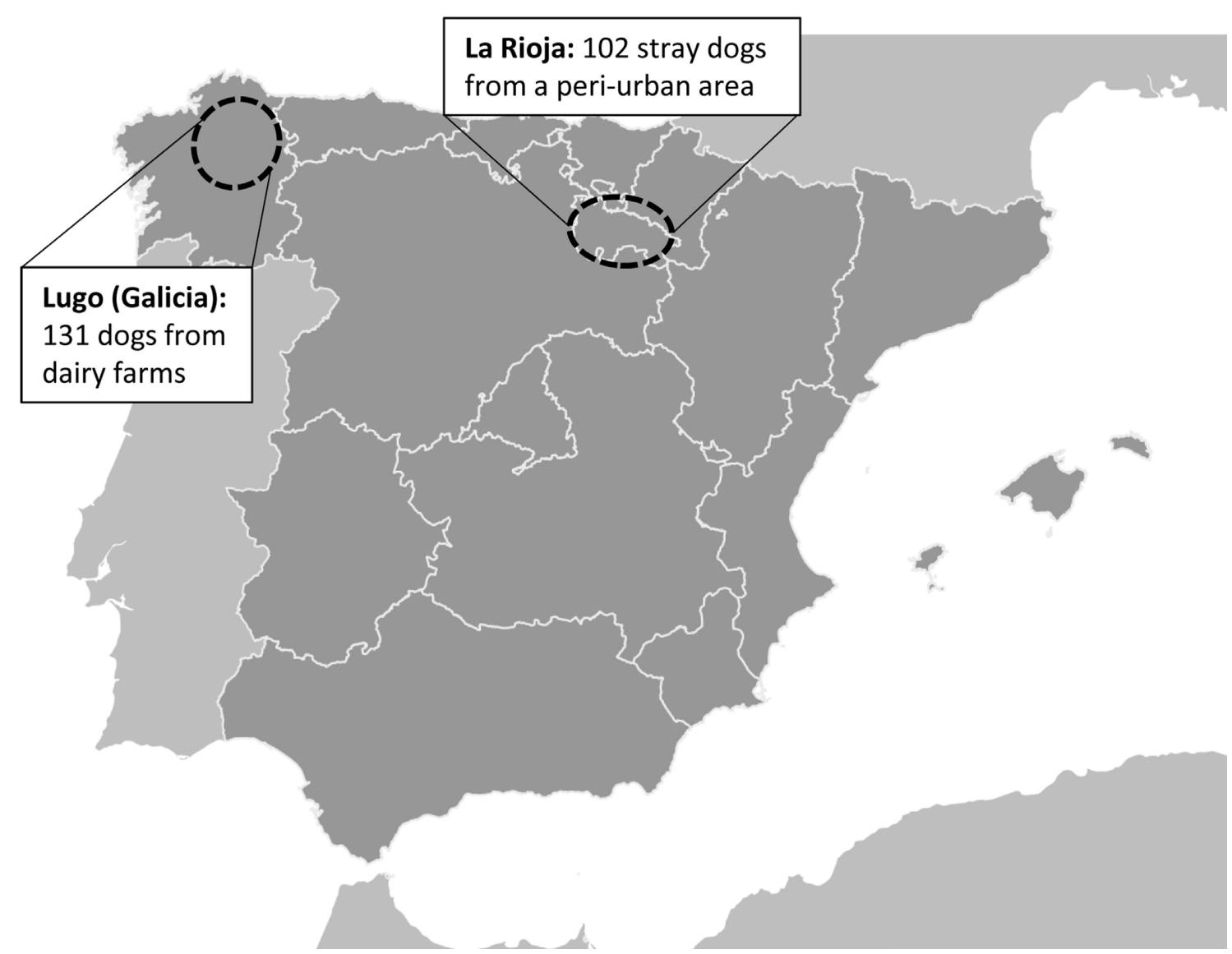

Figure 1. Location of the Spanish regions where dog samples were collected. 
detect Cryptosporidium oocysts, DNA was extracted from faeces (72 stray dogs and 119 farm dog samples) using a method described previously (McLauchlin et al., 1999). Briefly, this method uses a disruption with zirconia beads in the presence of guanidinium thiocyanate, followed by purification with activated silica. Subsequently, faecal DNA samples were analysed using a Cryptosporidium specific PCR as described previously (Xiao et al., 2000). To identify false-positive results, negative control samples (without template) were added to each set of DNA extractions. In farm dogs, data regarding age and housing (free or controlled access to the farm) were collected. Prevalence data were compared by Chi-square test $\left(X^{2}\right)$ at a significance level of $95 \%(P<0.05)$. Statistical analysis was carried out using GraphPad Prism 7 v.7.04 (San Diego, CA, USA) software.

\section{Results and Discussion}

Microscopically, gastrointestinal parasite forms found in the faeces of the dogs were identified as nematodes (Ancylostomatidae, Toxocara canis, Trichuris spp. and Toxascaris leonina), cestodes (Taeniidae) and protozoa (Cystoisospora spp. and Giardia). Cryptosporidium DNA was not detected in any of the faecal samples analysed by PCR. Table 1 shows the prevalence of the different gastrointestinal parasites found in stray and farm dogs. From the 233 dogs analysed, $63.5 \%$ (148) were positive for at least one intestinal parasite, indicating a high degree of intestinal parasitism in these animals. In accordance to our study, similar prevalence rates of intestinal parasites were reported in Spanish rural (52.4\%; Ares-Mazas et al., 1987) and shelter dogs (ranging from 61.8 to 71.6\%; Martínez-Moreno et al., 2007; Ortuño et al., 2014) and in Portugal (58.8\%; Cardoso et al., 2014; Mateus et al., 2014). In tropical countries such as Brazil, urban stray dogs also showed high prevalence rates of intestinal parasites (e.g. 87.1\%; Saldanha-Elias et al., 2019). However, lower prevalence ( $\leq 25 \%)$ were described in other European countries, such as Poland (Felsmann et al., 2017) or Italy (Liberato et al., 2018; Scaramozzino et al., 2018). All these differences may be explained by the climate, dog populations studied, geographical location, sampling protocols, anthelmintic usage or diagnostic techniques employed (Adell-Aledón et al., 2018).

Table 1. Detection of intestinal parasites by Telemann coprological analysis.

\begin{tabular}{|c|c|c|c|c|c|c|c|}
\hline & \multicolumn{2}{|c|}{ Stray dogs (102) } & \multicolumn{2}{|c|}{ Farm dogs (131) } & \multirow{2}{*}{$\chi^{2}$} & \multicolumn{2}{|c|}{ TOTAL (233) } \\
\hline & $n$ & $\%$ & $n$ & $\%$ & & $n$ & $\%$ \\
\hline Ancylostomatidae & 44 & 43.1 & 39 & 29.7 & $3.9 *$ & 83 & 35.6 \\
\hline Trichuris & 41 & 40.2 & 41 & 31.3 & 1.62 & 82 & 35.2 \\
\hline Toxocara canis & 19 & 18.6 & 8 & 6.1 & $7.6 * \star$ & 27 & 11.6 \\
\hline Toxascaris leonina & 14 & 13.7 & 3 & 2.3 & $9.4^{* \star}$ & 17 & 7.3 \\
\hline Cystoisospora & 7 & 6.9 & 5 & 3.8 & 0.5 & 12 & 5.1 \\
\hline Taenidae & 6 & 5.9 & 1 & 0.8 & $3.5^{\star}$ & 7 & 3 \\
\hline Giardia & 4 & 3.9 & 3 & 2.3 & 0.11 & 7 & 3 \\
\hline TOTAL & 74 & 72.5 & 77 & 58.8 & $4.2^{*}$ & 148 & 63.5 \\
\hline
\end{tabular}

$n$ : number of positive animals; $* \mathrm{P}<0.05 ; * \star \mathrm{P}<0.01$.

The parasites most frequently identified in our study were Ancylostomidae (35.6\%; 83/233) and Trichuris (35.2\%; $82 / 233$ ) and co-infections of both parasites were present in 14.1\% (33/233). From biological and epidemiological standpoints, a possible association between the presence of Trichuris and hookworms has also been described in infected dogs (Traversa et al., 2014). This fact could be accounted for by the accumulation of infective larvae or eggs in the environment that has a crucial role in the transmission of these dog intestinal nematodes. Likewise, Ancylostomatidae and Trichuris were the parasites more frequently detected in stray and shelter dogs in Italy (Liberato et al., 2018; Scaramozzino et al., 2018), Poland (Felsmann et al., 2017) or Brazil (Saldanha-Elias et al., 2019). In the case of hookworms, the predominant agricultural environment where most of these dogs roam provides protection to larvae from direct sunlight and dehydration, especially in unpaved areas where sanitation processes are ineffective. Moreover, the trans-mammary route is favoured by the lack of controls and treatments in these 
dog populations (Liberato et al., 2018). Interestingly, the prevalence in farm dogs with free access to the farm was significantly lower $(42.8 \% ; 24 / 56)$ than in dogs with controlled access $(66.1 \% ; 37 / 56)(P<0.05)$, especially for Ancylostomidae ( $16 \%$ vs $50 \% ; \mathrm{P}<0.05)$. This may be explained by the accumulation of faecal material (and therefore potential sources of infection) in a confined area inside the farm, since faeces are not usually collected and disposed of. Controlled-access dogs would have a more frequent contact with this faeces accumulation than those that freely enter and exit the farm.

Moreover, this potential environmental contamination of hookworms eggs (e.g. Ancylostoma caninum and Uncinaria stenocephala in Mediterranean area) poses a high risk of zoonotic human infection, as these species are known to cause cutaneous larva migrans syndrome. Although identification of Ancylostomidae species was not carried out, the high prevalence observed here points out that the presence of stray or farm dogs would lead to an increased exposure of humans to this zoonosis. In line with this, other potential zoonotic parasites were detected in our study, although the prevalence was low for Giardia (3\%), Taenidae (3\%; which could potentially be Echinococcus granulosus, the causative agent of hydatidosis) and T. canis (11.6\%, one of the causative agents of visceral larva migrans). In previous studies, canine giardiasis has been reported in a variety of dog populations (owned, sheltered, stray) with prevalence ranging from 1 to 38\% in Spain (Dado et al., 2012; Ortuño et al., 2014; Gil et al., 2017) or 25\% in Brazil (Saldanha-Elias et al., 2019). Taenidae eggs were scarcely detected. Although we were not able to gather information regarding anti-parasitic treatment records, the low prevalence of cestodes observed in our study could be explained by the prevention campaign against $E$. granulosus conducted by the Spanish Government and local councils in the last decades, consisting in a bi-annual praziquantel administration (Jiménez et al., 2002). As a matter of fact, in a previous study in the province of Álava (northern Spain), a low prevalence $(0.5 \%, 5 / 1040)$ of E. granulosus infection in dogs was also found (Benito et al., 2006). Prevalence rates ranging from 0.2 to $1.3 \%$ have also been reported in dogs from La Rioja (Jiménez et al., 2002). T. canis infections are found worldwide (including in the European canine populations) and it is one of the most widespread public health and economically important zoonoses in humans (Schnieder et al., 2011). Toxocara was the second more prevalent parasite detected in our study. However, the actual prevalence could be higher because adult dogs show lower prevalence and worm burdens (Schnieder et al., 2011). In our study, age data were collected for 112 farm dogs. When dogs $\leq 1$ year old were compared to dogs $>1$ year old, no significant differences were found. Nevertheless, dogs younger than 1 year comprised only $14.3 \%$ (16/112) of the studied population. Another important potential zoonotic parasite is Cryptosporidium, which was not detected in this study. We used PCR to detect its presence because this technique allows to detect a low number of parasites in faeces that would otherwise be difficult to detect using coprological examination. Nevertheless, the presence of PCR inhibitors in faecal samples hinders PCR detection. In this sense, we employed a previously described method for nucleic acid extraction (modified Boom's method), which has been demonstrated to avoid co-purification of PCR-inhibitors present in faeces (McLauchlin et al., 1999).

On the other hand, when the different dog populations were compared, the overall prevalence of intestinal parasites was significantly higher in stray dogs $(72.5 \%, 74 / 102)$ than in dairy farm dogs $(58.8 \%, 77 / 131)(P<0.05)$. Specifically, the presence of Ancylostomatidae, Toxocara, Toxascaris and Taenidae were more often detected in stray dogs $(\mathrm{P}<0.05)$. These results show that stray dogs are heavily parasitized, which could be related to the uncontrolled access to potentially infection sources and to the absence of anti-parasitic treatments. This fact is relevant because peri-urban stray dogs can easily spread different gastrointestinal parasites with zoonotic potential posing a high risk for humans in urban areas.

In summary, the high overall prevalence of intestinal parasites found in the present study may account for the little access to veterinary care and high exposure to infection of these dog populations. Environmental contamination by dog faeces is considered a risk factor to public health, as dogs can act as carriers of pathogenic agents transmissible to humans (Martínez-Moreno et al., 2007). Thus, a strict control of at-risk dog populations is crucial in order to limit public health problems derived from parasitic infections. A combination of strategic anthelmintic treatment programs, control of stray and farm dogs, and enhanced owner education and awareness is highly recommended for the control of intestinal parasites in dogs.

\section{Acknowledgements}

We would like to thank Belén Antonio and Marta Alonso (SALUVET group) for their excellent technical assistance. We also thank Azucena Pérez Palacios from "Dirección General de Salud y Consumo del Gobierno de La Rioja", Ignacio Arnáiz Seco from "Laboratorio de Sanidad y Producción Animal de Galicia" and farm veterinarians for samples and data collection. 


\section{References}

Adell-Aledón M, Köster PC, de Lucio A, Puente P, Hernández-de-Mingo M, Sánchez-Thevenet P, et al. Occurrence and molecular epidemiology of Giardia duodenalis infection in dog populations in eastern Spain. BMC Vet Res 2018; 14(1): 26. http://dx.doi. org/10.1186/s12917-018-1353-z. PMid:29357850.

Ares-Mazas ME, Sela-Pérez MC, Arias-Fernández MC. Epidemiology of intestinal parasite infections of dogs in Galicia. Rev Iber Parasitol 1987; 47: 335-339.

Balassiano BC, Campos MR, Menezes RC, Pereira MJ. Factors associated with gastrointestinal parasite infection in dogs in Rio de Janeiro, Brazil. Prev Vet Med 2009; 91(2-4): 234-240. http://dx.doi.org/10.1016/j.prevetmed.2009.05.030. PMid:19577316.

Benito A, Carmena D, Joseph L, Martínez J, Guisantes JA. Dog echinococcosis in northern Spain: Comparison of coproantigen and serum antibody assays with coprological exam. Vet Parasitol 2006; 142(1-2): 102-111. http://dx.doi.org/10.1016/j. vetpar.2006.06.011. PMid:16863681.

Cardoso AS, Costa IMH, Figueiredo C, Castro A, Conceição MAP. The occurrence of zoonotic parasites in rural dog populations from northern Portugal. J Helminthol 2014; 88(2): 203-209. http://dx.doi.org/10.1017/S0022149X13000047. PMid:23388655.

Dado D, Izquierdo F, Vera O, Montoya A, Mateo M, Fenoy S, et al. Detection of zoonotic intestinal parasites in public parks of Spain. Potential epidemiological role of microsporidia. Zoonoses Public Health 2012; 59(1): 23-28. http://dx.doi.org/10.1111/j.18632378.2011.01411.x. PMid:21824364.

Felsmann MZM, Michalski MM, Felsmann MZM, Sokół R, Szarek J, Strzyżewska-Worotyńska E. Invasive forms of canine endoparasites as a potential threat to public health - A review and own studies. Ann Agric Environ Med 2017; 24(2): 245-249. http://dx.doi.org/10.5604/12321966.1235019. PMid:28664702.

Gil H, Cano L, de Lucio A, Bailo B, de Mingo MH, Cardona GA, et al. Detection and molecular diversity of Giardia duodenalis and Cryptosporidium spp. in sheltered dogs and cats in Northern Spain. Infect Genet Evo/ 2017; 50: 62-69. http://dx.doi.org/10.1016/j. meegid.2017.02.013. PMid:28219812.

Jiménez S, Pérez A, Gil H, Schantz PM, Ramalle E, Juste RA. Progress in control of cystic echinococcosis in La Rioja, Spain: decline in infection prevalences in human and animal hosts and economic costs and benefits. Acta Trop 2002; 83(3): 213-221. http:// dx.doi.org/10.1016/S0001-706X(02)00091-8. PMid:12204394.

Liberato C, Berrilli F, Odorizi L, Scarcella R, Barni M, Amoruso C, et al. Parasites in stray dogs from Italy: prevalence, risk factors and management concerns. Acta Parasitol 2018; 63(1): 27-32. http://dx.doi.org/10.1515/ap-2018-0003. PMid:29351076.

Martínez-Moreno FJ, Hernández S, López-Cobos E, Becerra C, Acosta I, Martínez-Moreno A. Estimation of canine intestinal parasites in Córdoba (Spain) and their risk to public health. Vet Parasito/ 2007; 143(1): 7-13. http://dx.doi.org/10.1016/j.vetpar.2006.08.004. PMid:16971046.

Mateus TL, Castro A, Ribeiro JN, Vieira-Pinto M. Multiple zoonotic parasites identified in dog feces collected in ponte de Lima, Portugal: A potential threat to human health. Int J Environ Res Public Health 2014; 11(9): 9050-9067. http://dx.doi.org/10.3390/ ijerph110909050. PMid:25257358.

McLauchlin J, Pedraza-Díaz S, Amar-Hoetzeneder C, Nichols GL. Genetic characterization of Cryptosporidium strains from 218 patients with diarrhea diagnosed as having sporadic cryptosporidiosis. J Clin Microbiol 1999; 37(10): 3153-3158. http://dx.doi. org/10.1128/JCM.37.10.3153-3158.1999. PMid:10488169.

Ortuño A, Scorza V, Castellà J, Lappin M. Prevalence of intestinal parasites in shelter and hunting dogs in Catalonia, Northeastern Spain. Vet J 2014; 199(3): 465-467. http://dx.doi.org/10.1016/j.tvjl.2013.11.022. PMid:24445136.

Pierangeli NB, Soriano SV, Roccia I, Giménez J, Lazzarini LE, Grenóvero MS, et al. Heterogeneous distribution of human cystic echinococcosis after a long-term control program in Neuquén, Patagonia Argentina. Parasitol Int 2007; 56(2): 149-155. http:// dx.doi.org/10.1016/j.parint.2007.01.007. PMid:17317277.

Saldanha-Elias AM, Silva MA, Silva VO, Amorim SLA, Coutinho AR, Santos HA, et al. Prevalence of endoparasites in urban stray dogs from Brazil diagnosed with Leishmania, with potential for human zoonoses. Acta Parasitol 2019; 64(2): 352-359. http:// dx.doi.org/10.2478/s11686-019-00043-x. PMid:30941666.

Scaramozzino P, Carvelli A, lacoponi F, De Liberato C. Endoparasites in household and shelter dogs from Central Italy. Int J Vet Sci Med 2018; 6(1): 45-47. http://dx.doi.org/10.1016/j.ijvsm.2018.04.003. PMid:30255077.

Schnieder T, Laabs E-M, Welz C. Larval development of Toxocara canis in dogs. Vet Parasito/ 2011; 175(3-4): 193-206. http://dx.doi. org/10.1016/j.vetpar.2010.10.027. PMid:21095061.

Soriano SV, Pierangeli NB, Roccia I, Bergagna HFJ, Lazzarini LE, Celescinco A, et al. A wide diversity of zoonotic intestinal parasites infects urban and rural dogs in Neuquén, Patagonia, Argentina. Vet Parasitol 2010; 167(1): 81-85. http://dx.doi.org/10.1016/j. vetpar.2009.09.048. PMid:19864068. 
Intestinal parasites in outdoor dogs from Spain

Thienpont D, Rochette F, Vanparijs OFG. Diagnosis helminthiasis through coprological examination. Beerse, Belgium: Janssen Research Foundation; 1979.

Traversa D, Frangipane Di Regalbono A, Di Cesare A, La Torre F, Drake J, Pietrobelli M. Environmental contamination by canine geohelminths. Parasit Vectors 2014; 7(1): 67. http://dx.doi.org/10.1186/1756-3305-7-67. PMid:24524656.

Xiao L, Alderisio K, Limor J, Royer M, Lal AA. Identification of species and sources of Cryptosporidium oocysts in storm waters with a small-subunit rRNA-based diagnostic and genotyping tool. Appl Environ Microbio/ 2000; 66(12): 5492-5498. http://dx.doi. org/10.1128/AEM.66.12.5492-5498.2000. PMid:11097935. 